\title{
Perioperative Factors Associated with Tracheostomy use following Esophagectomy Surgery
}

\author{
Michelle Gerstman ${ }^{*}$, John Batty ${ }^{2}$, Gemma Friedlaender $^{3}$, Kabir Mohammed ${ }^{4}$, Matthew Hacking ${ }^{5}$ and \\ Timothy Wigmore ${ }^{5}$
}

${ }^{1}$ Consultant Anaesthetist, Peter MacCallum Cancer Centre, Melbourne, Australia

${ }^{2}$ Anaesthetic Specialty Trainee, Colchester Hospital University NHS Foundation Trust, United Kingdom

${ }^{3}$ Anaesthetic Specialty Trainee, Barnet Hospital, The Royal Free NHS Foundation Trust, United Kingdom

${ }^{4}$ Senior Statistician, Royal Marsden Foundation Trust, London, United Kingdom

${ }^{5}$ Consultant Anaesthetist, Royal Marsden Foundation Trust, London, United Kingdom

\begin{abstract}
Background: Esophagectomy surgery remains high risk with $36 \%$ of patients in the UK having a complication. Tracheostomy insertion can aid weaning from ventilation post-operatively and can be inserted at the time of surgery (elective) or postoperatively (delayed). We aimed to identify factors associated with elective and delayed tracheostomies, as well as differences in outcomes in each group.
\end{abstract}

\begin{abstract}
Methods: We retrospectively reviewed cases over a 5-year period.
Results: During this period 98 patients did not require a tracheostomy after esophagectomy surgery, 36 had an elective tracheostomy inserted and 23 required a delayed tracheostomy. An increased ASA (3-4), being a current or ex-smoker and an increased BMI were independent factors for having an elective tracheotomy inserted. An increased BMI was an independent risk factor for requiring a delayed tracheostomy. Patients with delayed tracheostomies had the longest ICU and hospital stay followed by the elective group. The 'no tracheostomy' group had the shortest ICU and hospital length of stay. There were no differences in mortality between the groups.
\end{abstract}

Conclusion: Patients who require a delayed tracheostomy after oesophageal surgery have longer ICU and hospital length of stay. This study demonstrates an association between an increased BMI and the need for a delayed tracheostomy. Patients with an increased BMI may benefit from the insertion of an elective tracheostomy on the day of surgery.

\section{Keywords}

Esophagectomy, Tracheostomy, Postoperative period, Respiratory insufficiency

\section{Introduction}

Esophagectomy is a major oncological surgical procedure, associated with significant morbidity and mortality [1,2]. In the United Kingdom (UK), there is a $16.9 \%$ respiratory complication rate with $36.4 \%$ of patients having some sort of complication. Thirty-day mortality is $1.9 \%$ and 90 day mortality $3.3 \%$ [2].

After esophagectomy, where feasible at our institution we aim to extubate on the day of surgery. A certain percentage of these patients will end up requiring a tracheostomy for a variety of medical and surgical reasons. However, in certain cases, such as patients with difficulty with oxygenation intraoperatively, complicated and prolonged surgery, severe lung disease or high inotrope requirements, it is not possible to extubate on the day of surgery [3-5]. In these cases, elective tracheostomy insertion at the completion of the esophagectomy is considered in our institution.
Tracheostomy insertion has several possible advantages over translaryngeal intubation. This includes improved access to the tracheobronchial tree for suctioning, oral hygiene and pulmonary toilet. Tracheostomy can increase patient comfort and decrease levels of sedation and their resultant side

*Corresponding author: Dr. Michelle Gerstman, Consultant Anaesthetist, Peter MacCallum Cancer Centre, 305 Grattan Street, Melbourne 3000, Australia, Tel: +61408175493

Accepted: February 02, 2021

Published online: February 04, 2021

Citation: Gerstman M, Batty J, Friedlaender G, et al. (2021) Perioperative Factors Associated with Tracheostomy use following Esophagectomy Surgery. J Clin Anesth Pain Manag 5(1):186-195

Copyright: (c) 2021 Gerstman M, et al. This is an open-access article distributed under the terms of the Creative Commons Attribution License, which permits unrestricted use, distribution, and reproduction in any medium, provided the original author and source are credited. 
effects such as need for inotropic support. The patient can potentially be weaned from the ventilator more rapidly [6-8]. There is some evidence that in the general ICU patient early tracheostomy insertion improves mortality versus late insertion however this is debated in the ICU literature [8-11]. Approximately $20 \%$ of Upper Gastro Intestinal surgeons in the UK who responded to a survey had sited or asked a colleague to site an elective tracheostomy [12].

There is limited published evidence regarding tracheostomy use in esophagectomy patients. Wessels, et al. showed a decreased length of mechanical ventilation, decreased length of ICU and hospital stay in patients in our institution who had an elective tracheostomy compared to a delayed tracheostomy [13].

Sakatoku, et al. found no difference in rates of pneumonia, atelectasis, hospital length of stay or 90-day mortality between high risk patients who had an elective prophylactic mini tracheostomy inserted and those who were not high risk and had no tracheostomy inserted. In their study, patients were considered high risk if they were over 80 years of age, had reduced pulmonary function (Forced expired volume in 1 second (FEV1) $<1.5 \mathrm{~L}$ or predicted FEV1 $<60 \%$ ), pneumonia, or aspiration noted on upper gastro intestinal imaging or had evidence of a vocal palsy on bronchoscopy after extubation. FEV1.0\% $<70 \%$ and vocal cord palsy were independent risk factors for requiring a delayed mini tracheostomy [14].

Tracheostomy insertion is not without risk. These risks can be divided into immediate risks such as hemorrhage or pneumothorax, short term risks such as blockage or tube displacement and long-term risks such as tracheal stenosis and tracheocutaneous fistula $[15,16]$. The definition and rates of complications vary in the published literature with an overall range of complications of 2.1 to $23 \%$ [17]. Rates of complications reported include minor bleeding 4.3-12.5\% [17,18], major bleeding 1.5-5\% [17], pneumothorax 0.5-1.6\% [17,19$21]$ and blockage or obstruction $0.46-6.5 \%[17,21,22]$. Long term complications include tracheoesophageal fistula with a risk of less than $1 \%[19,23]$ and tracheal stenosis $0.35-3.7 \%$ $[18,23,24]$. These potential complications of tracheostomy insertion need to be weighed up against potential benefits.

Currently, the decision to insert a tracheostomy in our institution is a result of a discussion between the anesthetic and surgical teams based on pre-morbid factors and the perceived surgical complexity. Patients are fully consented to the risks associated with elective tracheostomy as part of the preoperative general consenting process.

We defined "elective" tracheostomy as tracheostomy insertion intraoperatively and "delayed" as insertion during the post-operative period. Both the elective and tracheostomy groups had sedation weaned post insertion when clinically appropriate.

Our primary aim was to analyze the factors which are associated with use of elective tracheostomy in our patient population. We also aimed to compare outcomes in the 3 patient groups: No tracheostomy, elective tracheostomy and delayed tracheostomy. We included factors associated with increased morbidity or mortality as well as adverse shortterm outcomes [25-30].

\section{Methods}

We conducted a retrospective observational analysis of patients undergoing esophagectomies at the Royal Marsden over 5-years between September 2010 and December 2015. This study was approved by the hospital Committee for Clinical Research.

\section{Statistical analysis}

Descriptive analysis method was used to summarize the variables in the tracheostomy groups using counts and percentages and mean/median and standard deviation/range as appropriate. Multinomial logistic regression analysis method was used to determine factors/variables that predict patients' allocation to the elective, delayed and no tracheostomy groups.

Patients' ICU length of stay, total hospital length of stay and total ventilation hours were compared between the 3 groups using Analysis of variance (ANOVA) or Kruskal-Wallis' non-parametric method as appropriate.

Rates of mortality at 30 days and at 1 year, readmission to ICU, renal, cardiovascular, neurological, wound, return to theatre, infectious complication were assessed between the groups using binary logistic regression. Details on the number and percentages, odds ratios and $95 \%$ confidence interval were reported.

Receiver operator characteristics curves were used to determine the best BMI cut off point that discriminated between the need for each of elective and delayed tracheostomies.

The sample size and duration of the study was chosen based on the ability to have the most complete data set from the time of the commencement of electronic anesthetic records.

\section{Results}

A total of 157 patients underwent esophagectomy surgery. Of those 98 did not require tracheostomies, 36 had an elective tracheostomy and 23 a delayed tracheostomy. Baseline data is summarized in Table 1. There were no differences in age or gender, tumor staging, neoadjuvant chemotherapy, pulmonary function (FEV1), forced vital capacity (FVC), max work performed on cardiopulmonary exercise testing (CPET), laparoscopic assisted versus open technique, intraoperative fluid given or blood loss between the groups. There were differences in ASA status, APACHE 2 score and possum score, as well as BMI, smoking status, anaerobic threshold (AT) and maximum oxygen consumption (VO2 max) on CPET and complexity of surgery ( 2 stage versus 3 stage and duration). These differences are further quantified in the univariate and multivariate analysis below.

\section{Univariate analysis}

Patients who had an elective tracheostomy when compared to the no tracheostomy group had higher ASA scores $(R R R=6.64(2.86-15.40), p<0.001)$, worse POSSUM (RRR 1.11 (1.02-1.20), $p=0.014)$ and APACHE 2 scores (RRR 1.15 (1.06- 
Citation: Gerstman M, Batty J, Friedlaender G, et al. (2021) Perioperative Factors Associated with Tracheostomy use following Esophagectomy Surgery. J Clin Anesth Pain Manag 5(1):186-195

Table 1: Baseline characteristics of no tracheostomy, elective tracheostomy and delayed tracheostomy groups.

\begin{tabular}{|c|c|c|c|c|}
\hline & No tracheostomy & Elective tracheostomy & Delayed tracheostomy & $P$ value \\
\hline $\begin{array}{l}\text { Patients } \\
\text { number }\end{array}$ & 98 & 36 & 23 & \\
\hline $\begin{array}{l}\text { Age (years) } \\
\text { Mean }(S D)\end{array}$ & $62.62(9.64)$ & $64.11(9.51)$ & $60.30(9.37)$ & 0.333 \\
\hline $\begin{array}{l}\text { Male } \\
n(\%)\end{array}$ & $83(85)$ & $32(89)$ & $21(92)$ & 0.635 \\
\hline $\begin{array}{l}\text { ASA 1-2 } \\
\text { ASA 3-4 } \\
n(\%)\end{array}$ & $\begin{array}{l}73(74) \\
25(26)\end{array}$ & $\begin{array}{l}11(31) \\
25(69)\end{array}$ & $\begin{array}{l}13(57) \\
10(43)\end{array}$ & $<0.001$ \\
\hline $\begin{array}{l}\text { APACHE II } \\
\text { Mean (SD) }\end{array}$ & $16.45(4.81)$ & $20.09(5.23)$ & $18.19(5.46)$ & 0.001 \\
\hline $\begin{array}{l}\text { BMI } \\
\text { Mean (SD) }\end{array}$ & $26.54(4.00)$ & $29.21(7.04)$ & $30.12(5.08)$ & 0.002 \\
\hline $\begin{array}{l}\text { Non-smoker } \\
\text { Ex-smoker } \\
\text { Current smoker } \\
n(\%)\end{array}$ & $\begin{array}{l}41(42) \\
50(51) \\
7(7)\end{array}$ & $\begin{array}{l}2(6) \\
27(75) \\
7(19)\end{array}$ & $\begin{array}{l}8(35) \\
12(52) \\
3(13)\end{array}$ & 0.002 \\
\hline $\begin{array}{l}\text { Nodes negative } \\
\text { Nodes positive } \\
n(\%)\end{array}$ & $\begin{array}{l}52(54) \\
44(46)\end{array}$ & $\begin{array}{l}23(66) \\
12(34)\end{array}$ & $\begin{array}{l}10(43) \\
13(57)\end{array}$ & 0.236 \\
\hline $\begin{array}{l}\text { Neoadjuvant chemotherapy } \\
n(\%)\end{array}$ & 77 (79) & $29(81)$ & $17(74)$ & 0.600 \\
\hline $\begin{array}{l}\text { Completed neoadjuvant chemotherapy } \\
n(\%)\end{array}$ & $71(72)$ & $25(69)$ & $17(74)$ & 0.337 \\
\hline $\begin{array}{l}\text { Preoperative POSSUMP } \\
\text { Median (IQR) }\end{array}$ & $19(15-22)$ & $21(18-25)$ & $16(14-21)$ & 0.035 \\
\hline $\begin{array}{l}\text { FEV1 (liter) + } \\
\text { mean (SD) }\end{array}$ & $3.21(0.68)$ & $3.07(1.03)$ & $2.69(0.69)$ & 0.207 \\
\hline $\begin{array}{l}\text { FVC (liter) + } \\
\text { mean (SD) }\end{array}$ & $4.29(0.97)$ & $4.05(0.98)$ & $3.67(0.72)$ & 0.170 \\
\hline $\begin{array}{l}\text { Anaerobic threshold }(\mathrm{AT})^{*} \mathrm{VO}_{2}(\mathrm{ml} / \mathrm{kg} / \mathrm{min}) \\
\text { mean }(S D)\end{array}$ & $12.17(3.06)$ & $10.65(2.51)$ & $11.26(2.00)$ & 0.043 \\
\hline $\begin{array}{l}\mathrm{VO}_{2}-\mathrm{Max}(\mathrm{ml} / \mathrm{kg} / \mathrm{min})^{*} \\
\text { mean }(S D)\end{array}$ & $19.10(4.32)$ & $16.83(3.48)$ & $17.01(3.71)$ & 0.023 \\
\hline $\begin{array}{l}\text { AT work (Watts) } \\
\text { mean (SD) }\end{array}$ & 71.84 (27.94) & $64.60(30.51)$ & $69.24(22.26)$ & 0.533 \\
\hline $\begin{array}{l}\text { Lap-assisted } \\
\text { Open } \\
n(\%)\end{array}$ & $\begin{array}{l}49(50) \\
49(50)\end{array}$ & $\begin{array}{l}16(44) \\
20(56)\end{array}$ & $\begin{array}{l}8(35) \\
15(65)\end{array}$ & 0.404 \\
\hline $\begin{array}{l}2 \text { Stage } \\
3 \text { Stage } \\
n(\%)\end{array}$ & $\begin{array}{l}97(99) \\
1(1)\end{array}$ & $\begin{array}{l}31(86) \\
5(14)\end{array}$ & $\begin{array}{l}23(100) \\
0\end{array}$ & 0.006 \\
\hline $\begin{array}{l}\text { Duration surgery } \\
\text { (Minutes) } \\
\text { Median (IQR) }\end{array}$ & $399(73)$ & $475(64)$ & $434(98)$ & $<0.001$ \\
\hline $\begin{array}{l}\text { Intraoperative fluid (liter) } \\
\text { Median (SD) }\end{array}$ & $2.96(1.55)$ & $3.50(1.06)$ & $2.90(1.40)$ & 0.131 \\
\hline
\end{tabular}


Citation: Gerstman M, Batty J, Friedlaender G, et al. (2021) Perioperative Factors Associated with Tracheostomy use following Esophagectomy Surgery. J Clin Anesth Pain Manag 5(1):186-195

\section{Estimated blood loss (ml)}

Median (IQR)

$500(300-755)$

$450(300-550)$

$546(400-682)$

0.711

*Not all patients underwent cardiopulmonary exercise testing. Numbers were: no tracheostomy 57/98, elective tracheostomy $30 / 36$ and Delayed tracheostomy 18/23.

+Not all patients underwent pulmonary function testing. Numbers were: No tracheostomy 49/98, elective tracheostomy $27 / 36$ and delayed tracheostomy $9 / 23$.

SD: Standard deviation; n: Number; ASA: American Society of Anesthesiologists physical status classification system; APACHE: Acute Physiology and Chronic Health Evaluation; BMI: Body Mass Index; POSSUM P: Physiological and Operative Severity Score for the enUmeration of Mortality and Morbidity Portsmouth; IQR: Interquartile Range; FEV1: Forced Expiratory Volume in one second; FVC: Forced Vital Capacity; AT: Anaerobic Threshold; $\mathrm{ml} / \mathrm{kg} / \mathrm{min}$ : milliliters per kilogram per minute; $\mathrm{VO}_{2}$ max: Maximal oxygen consumption.

Table 2: Univariate analysis of peri-operative factors associated with having an elective or delayed tracheostomy.

\begin{tabular}{|c|c|c|c|c|}
\hline & \multicolumn{2}{|l|}{ No vs. elective } & \multicolumn{2}{|l|}{ No vs. delayed } \\
\hline & $\operatorname{RRR}(95 \% \mathrm{Cl})$ & $P$ value & RRR $(95 \% \mathrm{Cl})$ & $P$ value \\
\hline ASA 1 - 2 & 1 & & 1 & \\
\hline ASA 3 - 4 & $6.64(2.86-15.40)$ & $<0.001$ & $2.25(0.88-5.76)$ & 0.092 \\
\hline APACHE II & $1.15(1.06-1.25)$ & 0.001 & $1.08(0.98-1.19)$ & 0.142 \\
\hline POSSUMP & $1.11(1.02-1.20)$ & 0.014 & $0.95(0.84-1.07)$ & 0.398 \\
\hline BMI & $1.12(1.03-1.21)$ & 0.008 & $1.15(1.05-1.27)$ & 0.003 \\
\hline \multicolumn{5}{|l|}{ Smoking status: } \\
\hline Non-smoker & 1 & & 1 & \\
\hline Ex-smoker & $10.8(2.42-48.17)$ & 0.002 & $1.2(0.45-3.22)$ & 0.717 \\
\hline Current smoker & $20.0(3.42-116.8)$ & 0.001 & $2.14(0.45-10.11)$ & 0.335 \\
\hline AT & $0.78(0.64-0.96)$ & 0.019 & $0.86(0.69-1.08)$ & 0.189 \\
\hline VO2-Max & $0.86(0.75-0.97)$ & 0.018 & $0.87(0.74-1.02)$ & 0.075 \\
\hline \multicolumn{5}{|l|}{ Surgical stage } \\
\hline Stage 2 & 1 & 0.014 & - & - \\
\hline Stage 3 & $15.63(1.76-138.9)$ & & & \\
\hline Duration of surgery & $1.01(1.01-1.02)$ & $<0.001$ & $1.01(1.00-1.01)$ & 0.048 \\
\hline
\end{tabular}

RRR: Relative Risk Ratio; ASA: American Society of Anesthesiologists physical status classification system; APACHE: Acute Physiology and Chronic Health Evaluation; BMI: Body Mass Index; POSSUM P: Physiological and Operative Severity Score for the enUmeration of Mortality and Morbidity, Portsmouth; AT: Anaerobic Threshold; $\mathrm{VO}_{2}$ max: Maximal oxygen consumption.

1.25) $\mathrm{p}=0.001)$ and had higher BMIs (RRR $1.12(1.03-1.21) \mathrm{p}$ $=0.008)$. They were more likely to be ex or current smokers (RRR 10.8 (2.42-48.17) $p=0.002$ and RRR 20.0 (3.42-116.8) $\mathrm{p}=0.001$ respectively) and had a lower anaerobic threshold (RRR $0.78(0.64-0.96 p=0.019)$ and VO2 max (RRR 0.86 $(0.75-0.97) p=0.018)$. More had 3 stage procedures (RRR $15.63(1.76-138.9) \mathrm{p}=0.014)$ and their surgery was longer (RRR 1.01 (1.01-1.02), p < 0.001). Patients who required a delayed tracheostomy had higher BMIs (RRR 1.15 (1.05-1.27) $p$ $=0.003$ ) and longer duration of surgery (RRR 1.01 (1.00-1.01) $p=0.048$ ) than those who did not require a tracheostomy. See Table 2 for further details.

\section{Multivariate analysis}

Factors which continued to be significant with multivariate analysis in the elective tracheostomy group versus no tracheostomy group were ASA (RRR 7.12 (2.75-18.39), p < 0.001), Smoking status (ex RRR $10.05(2.08-48.54) p=0.013$ and current RRR $27.24(3.86-192.32) p=0.004)$ and BMI (RRR 1.14 (1.03-1.26), $\mathrm{p}=0.015)$. BMI was also significant when comparing delayed versus the no tracheostomy group (RRR $1.20(1.08-1.34) p=0.001)$. See Table 3 for further details.

\section{Outcome data}

Patients who did not require a tracheostomy had the shortest ICU and hospital stay (median 6 and 14 days respectively). Patients who had an elective tracheostomy had a median ICU stay of 10 days and hospital stay of 14 days. Patients who required a delayed tracheostomy had the longest ICU and hospital stay (median 19 and 27 days respectively; $p<$ 0.001 ). Patients with a delayed tracheostomy had the longest number of hours ventilated (median 336 hours), followed by the elective tracheostomy group (median 166 hours). The no tracheostomy group required ventilation for the shortest time (median 17 hours; $p<0.001$ ). See Table 4 for further details. 
Citation: Gerstman M, Batty J, Friedlaender G, et al. (2021) Perioperative Factors Associated with Tracheostomy use following Esophagectomy Surgery. J Clin Anesth Pain Manag 5(1):186-195

Table 3: Multivariate analysis of peri-operative factors associated with having an elective or delayed tracheostomy.

\begin{tabular}{|l|l|l|l|l|}
\hline \multicolumn{2}{|l|}{ No vs. Elective } & p-value & No vs. Delayed \\
\hline Variable & RRR (95\% Cl) & & RRR (95\% CI) & p-value \\
\hline ASA: & 1 & $<0.001$ & 1 & 0.115 \\
$\mathbf{1}-\mathbf{2}$ & $7.12(2.75-18.39)$ & & $2.25(0.82-6.19)$ & \\
$\mathbf{3}-\mathbf{4}$ & $1.14(1.03-1.26)$ & 0.015 & $1.20(1.08-1.34)$ & 0.001 \\
\hline BMI & & & & \\
\hline $\begin{array}{l}\text { Smoking status: } \\
\text { Non-smoker }\end{array}$ & 1 & & 1 & 0.823 \\
\hline $\begin{array}{l}\text { Ex-smoker } \\
\text { Current smoker }\end{array}$ & $10.05(2.08-48.54)$ & 0.013 & $0.88(0.30-2.61)$ & 0.109 \\
\hline
\end{tabular}

RRR: Relative Risk Ratio; Cl: Confidence Interval; ASA: American Society of Anesthesiologists physical status classification system; BMI: Body Mass Index.

Table 4: ICU, hospital length of stay and ventilation duration in each tracheostomy group.

\begin{tabular}{|l|l|l|l|l|}
\hline OUTCOME Variables & No Tracheostomy & Elective Tracheostomy & Delayed Tracheostomy & p-value \\
\hline $\begin{array}{l}\text { ICU stay (days): } \\
\text { Median (IQR) }\end{array}$ & $6(5-8)$ & $10(8-14)$ & $19(14-27)$ & $<0.001$ \\
\hline $\begin{array}{l}\text { ICU stay - (Log days) } \\
\text { Mean (SD) }\end{array}$ & $1.85(0.35)$ & $2.40(0.49)$ & $2.96(0.43)$ & $<0.001$ \\
\hline $\begin{array}{l}\text { Hospital stay - (days) } \\
\text { Median (IQR) }\end{array}$ & $14(11-18)$ & $14(14-29)$ & $27(20-40)$ & $<0.001$ \\
\hline $\begin{array}{l}\text { Total ventilation hours: } \\
\text { Median (IQR) }\end{array}$ & $17(2-32)$ & $166(123-286)$ & $336(216-504)$ & $<0.001$ \\
\hline
\end{tabular}

IQR: Interquartile Range.

Table 5: Pneumonia, surgical complications, return to theatre and mortality data for each tracheostomy group.

\begin{tabular}{|c|c|c|c|c|c|}
\hline & Variables & $\begin{array}{l}\text { No } \\
\text { n (\%) }\end{array}$ & $\begin{array}{l}\text { Yes } \\
\text { n (\%) }\end{array}$ & Odds Ratio $(95 \% \mathrm{Cl})$ & $p$-value \\
\hline Pneumonia & $\begin{array}{l}\text { No } \\
\text { Delayed } \\
\text { Elective }\end{array}$ & $\begin{array}{l}52(53) \\
4(17) \\
11(31)\end{array}$ & $\begin{array}{l}46(47) \\
19(83) \\
25(69)\end{array}$ & $\begin{array}{l}1 \\
5.37(1.70-16.94) \\
2.57(1.14-5.79)\end{array}$ & $\begin{array}{l}0.003 \\
0.004 \\
0.023\end{array}$ \\
\hline $\begin{array}{l}\text { Surgical } \\
\text { complication }\end{array}$ & $\begin{array}{l}\text { No } \\
\text { Delayed } \\
\text { Elective }\end{array}$ & $\begin{array}{l}85(87) \\
13(57) \\
31(86)\end{array}$ & $\begin{array}{l}13(13) \\
10(43) \\
5(14)\end{array}$ & $\begin{array}{l}1 \\
5.03(1.83-13.81) \\
1.05(0.35-3.20)\end{array}$ & $\begin{array}{l}0.005 \\
0.002 \\
0.925\end{array}$ \\
\hline Theatre return & $\begin{array}{l}\text { No } \\
\text { Delayed } \\
\text { Elective }\end{array}$ & $\begin{array}{l}92(94) \\
18(78) \\
35(97)\end{array}$ & $\begin{array}{l}6(6) \\
5(22) \\
1(3)\end{array}$ & $\begin{array}{l}1 \\
4.26(1.17-15.47) \\
0.44(0.05-3.77)\end{array}$ & $\begin{array}{l}0.036 \\
0.028 \\
0.452\end{array}$ \\
\hline $\begin{array}{l}\text { Mortality } \\
30 \text { days }\end{array}$ & $\begin{array}{l}\text { No } \\
\text { Delayed } \\
\text { Elective }\end{array}$ & $\begin{array}{l}96(98) \\
22(96) \\
35(97)\end{array}$ & $\begin{array}{l}2(2) \\
1(4) \\
1(3)\end{array}$ & $\begin{array}{l}1 \\
2.18(0.19-25.15) \\
1.37(0.12-15.60)\end{array}$ & 0.815 \\
\hline $\begin{array}{l}\text { Mortality } \\
1 \text { year }\end{array}$ & $\begin{array}{l}\text { No } \\
\text { Delayed } \\
\text { Elective }\end{array}$ & $\begin{array}{l}94(96) \\
20(87) \\
35(97)\end{array}$ & $\begin{array}{l}4(4) \\
3(13) \\
1(3)\end{array}$ & $\begin{array}{l}1 \\
3.53(0.73-16.99) \\
0.67(0.07-6.22)\end{array}$ & 0.164 \\
\hline
\end{tabular}


Citation: Gerstman M, Batty J, Friedlaender G, et al. (2021) Perioperative Factors Associated with Tracheostomy use following Esophagectomy Surgery. J Clin Anesth Pain Manag 5(1):186-195

Post-hoc pairwise comparison p-values were adjusted by Bonferroni method for ICU, hospital stay and ventilation hours. Pairwise tests are significantly different for the ICU stay between all groups as well as for hospital stay and total ventilation hours between no tracheostomy versus both elective and delayed groups. However, this is not the case between the elective and delayed groups whose hospital stay and total ventilation hours showed no significant differences with $p$-values 0.116 and 0.448 respectively.

Ventilator acquired pneumonia was more common in both elective and delayed tracheostomy groups versus the no tracheostomy group $(p=0.023$ and $p=0.004$ respectively). There were more surgical complications and returns to theatre for the delayed versus no tracheostomy group ( $p=$ 0.002 and $p=0.028$ respectively). There was no statistically significant difference in mortality rates at both 30 days and 1 year (see Table 5).

The indication for a delayed tracheostomy was often multifactorial but there was always a respiratory component including difficulty with ventilation, inability to clear secretions, pneumonia and likely long respiratory wean (see Supplementary Tables).

Receiver operator curves were used to quantify the increased BMI associated with both elective and delayed tracheostomies. For the elective group, a BMI of 27.8 had a sensitivity of $60 \%$ and specificity of $60 \%$. For the delayed group, a BMI of 28.0 had a sensitivity of $74 \%$ and specificity of $62 \%$.

\section{Discussion}

There is minimal published data regarding the use of peri-operative tracheostomies for patients undergoing an esophagectomy. In our institution, we aim to identify patients who are at increased risk of needing a post-operative tracheostomy and insert them early. In this study, we have showed that we inserted tracheostomies electively in patients with higher ASA scores, worse POSSUM and APACHE 2 scores, higher BMIs, ex or current smokers with lower anaerobic threshold and VO2 max and those undergoing longer surgery. These patients have a shorter ICU length of stay than those who have a delayed tracheostomy.

The only factor identified as having a significant difference between the no tracheostomy and delayed tracheostomy group is an increased BMI. Patients requiring a delayed tracheostomy have the longest ICU and hospital lengths of stay. In a recent meta-analysis comparing esophagectomy patients with a $\mathrm{BMI}$ of less than 30 to patients with a $\mathrm{BMI}$ equal to or greater than 30 showed patients with higher BMls were at increased risk of anastomotic leak but had better 5-year survival. In this meta-analysis there was no difference found in pulmonary complications, reoperation, bleeding or early mortality [3].

There are a number of peri-operative factors that contribute to a patient requiring a delayed tracheostomy and this group had more surgical complications with a higher number needing to return to theatre. When the delayed tracheostomy cases are considered individually, however, they all had the tracheostomy inserted for respiratory indications and some patients with surgical complications did not require a tracheostomy.

Prior research found FEV $1.0 \%<70 \%$ and vocal cord palsy were independent risk factors for requiring a delayed mini tracheostomy [7]. We did not specifically examine patients for vocal cord palsy but did not find FEV1 to be associated with delayed tracheostomies. This study was however not powered for this outcome and there was a trend towards a decreased FEV1 and FVC in patients requiring a delayed tracheotomy (RRR 0.45 (0.18-1.11) and 0.49 (0.22-1.09) respectively).

A strength of this study is that we systematically searched for all esophagectomies performed in a high-volume center over a 5-year period. As a quaternary referral hospital, we are often asked to do cases which are considered too high risk at other institutions which may contribute to the overall higher rates of tracheostomies in our population.

Although this research has many strengths, it has a number of limitations. Firstly, it is not a randomized controlled trial. It would however be difficult to perform a randomized controlled trial which is why this research is valuable.

We hypothesize that the return to baseline (no tracheostomy) in the high-risk tracheostomy group is due to the treatment effect of elective tracheostomy insertion however it is possible that the reason for no difference in some cases is that the elective tracheostomy made no difference in the patients' outcomes. In these cases, patients may not have needed a tracheostomy and thus exposing them to the risk of a tracheostomy. It is difficult to determine if this is the case in this retrospective analysis.

The delayed tracheostomy group did have a higher number of surgical complications. It is plausible that this contributed to a higher ICU hospital length of stay. Given this is not a randomized controlled trial, it is not possible to determine if the surgical complications led to the need for a tracheostomy.

Analgesia techniques were not specifically studied in this research project which is a weakness of this study. Patients had either an epidural inserted or intrathecal local anesthetic and morphine with a paravertebral catheter and a PCA.

The aim of this study was to identify factors associated with elective and delayed tracheotomies and compare outcomes. In this institution, we continue to insert elective tracheostomies, and the relatively high use (in comparison to other centers) reflects a combination of surgical complexity and patient morbidity as a tertiary/quaternary referral center. This research is unable to conclusively advocate the use of elective tracheostomy in high risk esophagectomy patients nor does it conclusively demonstrate that elective tracheostomies should not be used. As a randomized controlled trial would be difficult to perform, clinical judgement needs to be used. There are potential risks associated with tracheostomy insertion which must also be considered.

\section{Conclusion}

This study shows patients undergoing an elective tracheostomy in our institution were more likely to have higher 
BMIs, to have smoked, to have had longer surgery and had a lower anaerobic threshold and VO2 max. The need for a delayed tracheostomy was associated with higher BMls and a BMI of 28 had a sensitivity of $74 \%$ and specificity of $62 \%$ in this group. Patients who had a delayed tracheostomy had the longest ICU and hospital lengths of stay.

\section{Authors Declaration}

No funding or competing interests declared.

\section{References}

1. Rutegård M, Lagergren P, Rouvelas I, et al. (2012) Surgical complications and long-term survival after esophagectomy for cancer in a nationwide Swedish cohort study. Eur J Surg Oncol 38 555-561.

2. National Oesophago-Gastric Cancer Audit (2017) 2017 annual report.

3. Mengardo V, Pucetti F, Mc Cormack O, et al. (2017) The impact of obesity on esophagectomy: A meta-analysis. Diseases of the Esophagus 31.

4. Imai T, Abe T, Uemura N, et al. (2018) Immediate extubation after esophagectomy with three-field lymphadenectomy enables early ambulation in patients with thoracic esophageal cancer. Esophagus 15: 165-172.

5. Lanuti M, de Delva PE, Maher A, et al. (2006) Feasibility and outcomes of an early extubation policy after esophagectomy. Ann Thorac Surg 82: 2037-2041.

6. Lin WC, Chen CW, Wang JD, et al. (2015) Is tracheostomy a better choice than translaryngeal intubation for critically ill patients requiring mechanical ventilation for more than 14 days? A comparison of short-term outcomes. BMC Anesthesiol 15: 181.

7. Freeman BD, Morris PE (2012) Tracheostomy practice in adults with acute respiratory failure. Crit Care Med 40: 2890-2896.

8. Szakmany T, Russell P, Wilkes AR, et al. (2014) Effect of early tracheostomy on resource utilization and clinical outcomes in critically ill patients: Meta-analysis of randomized controlled trials. Br J Anaesth 114: 396-405.

9. Keeping A (2016) Early versus late tracheostomy for critically ill patients: A clinical evidence synopsis of a recent cochrane review. Can J Respir Ther 52: 27-28.

10. Andriolo BN, Andriolo RB, Saconato H, et al. (2015) Early versus late tracheostomy for critically ill patients. Cochrane Database Syst Rev 1.

11. Terragni PP, Antonelli M, Fumagalli R, et al. (2010) Early vs late tracheotomy for prevention of pneumonia in mechanically ventilated adult ICU patients: A randomized controlled trial. JAMA 303: 1483-1489.

12. Hanna-Jumma S, Preston S, Creagh-Brown B (2016) Survey of the role of elective perioperative tracheostomy and post-operative NIV in oesophago-gastric (OG) surgical patients. British Journal of Surgery, 104-209.

13. Wessels K, Gruber P, Hacking M, et al. (2012) Esophagogastrectomy surgery: The role for peri-operative tracheostomy in reducing morbidity and mortality. American Journal of Respiratory and Critical Care Medicine.

14. Sakatoku Y, Fukaya M, Miyata K, et al. (2017) Clinical value of a prophylactic minitracheostomy after esophagectomy: Analysis in patients at high risk for postoperative pulmonary complications. BMC Surgery 17: 120.

15. Lewith $H$, Athanassoglou $V$ (2019) Update on management of tracheostomy. BJA Education 19: 370-376.

16. de Kleijn BJ, Wedman J, Zijlstra JG, et al. (2019) Short- and longterm complications of surgical and percutaneous dilatation tracheotomies: A large single-centre retrospective cohort study. Eur Arch Otorhinolaryngol 276: 1823-1828.

17. Glossop A, Meekings TC, Hutchinson SP, et al. (2011) Complications following tracheostomy insertion in critically ill patients -experience from a large teaching hospital. Journal of the Intensive Care Society 12: 301-306.

18. Dempsey GA, Grant CA, Jones TM (2010) Percutaneous tracheostomy: A 6 yr prospective evaluation of the single tapered dilator technique. Br J Anaesth 105: 782-788.

19. Cipriano A, Mao ML, Hon HH, et al. (2015) An overview of complications associated with open and percutaneous tracheostomy procedures. Int J Crit IIIn Inj Sci 5: 179-188.

20. Tobler WD Jr, Mella JR, Ng J, et al. (2012) Chest X-ray after tracheostomy is not necessary unless clinically indicated. World J Surg 36: 266-269.

21. Díaz-Regañón G, Miñambres E, Ruiz A, et al. (2008) Safety and complications of percutaneous tracheostomy in a cohort of 800 mixed ICU patients. Anaesthesia 63: 1198-1203.

22. Barbetti JK, Nichol AD, Choate KR, et al. (2009) Prospective observational study of postoperative complications after percutaneous dilatational or surgical tracheostomy in critically ill patients. Crit Care Resusc 11: 244-249.

23. Hill BB, Zweng TN, Maley RH, et al. (1996) Percutaneous dilational tracheostomy: Report of 356 cases. J Trauma 41: 238-243.

24. Kearney PA, Griffen MM, Ochoa JB, et al. (2000) A single-center 8-year experience with percutaneous dilational tracheostomy. Ann Surg 231: 701-709.

25. Warnell I, Chincholkar M, Eccles M (2015) Predicting perioperative mortality after oesophagectomy: $A$ systematic review of performance and methods of multivariate models. $\mathrm{Br} J$ Anaesth 114: $32-43$.

26. Wright CD, Kucharczuk JC, O'Brien SM, et al. (2009) Predictors of major morbidity and mortality after esophagectomy for esophageal cancer: A society of thoracic surgeons general thoracic surgery database risk adjustment model. J Thorac Cardiovasc Surg 137: 587-595.

27. Ferguson MK, Durkin AE (2002) Preoperative prediction of the risk of pulmonary complications after esophagectomy for cancer. J Thorac Cardiovasc Surg 123: 661-669.

28. Tekkis PP, McCulloch P, Poloniecki JD, et al. (2004) Risk-adjusted prediction of operative mortality in oesophagogastric surgery with O-POSSUM. Br J Surg 91: 288-295.

29. Reeh M, Metze J, Uzunoglu FG, et al. (2016) The PER (preoperative esophagectomy risk) score: A simple risk score to predict short-term and long-term outcome in patients with surgically treated esophageal cancer. Medicine (Baltimore) 95: e2724.

30. Janowak CF, Blasberg JD, Taylor L, et al. (2015) The surgical Apgar score in esophagectomy. J Thorac Cardiovasc Surg 150: 806-812. 
Citation: Gerstman M, Batty J, Friedlaender G, et al. (2021) Perioperative Factors Associated with Tracheostomy use following Esophagectomy Surgery. J Clin Anesth Pain Manag 5(1):186-195

\section{Supplementary Tables}

Table 6: Other baseline characteristics of each tracheostomy group.

\begin{tabular}{|c|c|c|c|c|}
\hline & No tracheostomy & Elective tracheostomy & Delayed tracheostomy & $P$ value \\
\hline $\begin{array}{l}\text { WHO PS } \\
0 \\
1 \\
2 \\
3\end{array}$ & $\begin{array}{l}45 \\
47 \\
4 \\
2\end{array}$ & $\begin{array}{l}13 \\
16 \\
5 \\
1\end{array}$ & $\begin{array}{l}9 \\
11 \\
2 \\
1\end{array}$ & 0.419 \\
\hline $\begin{array}{l}\text { Pre-operative nutritional support } \\
n(\%)\end{array}$ & $52(53)$ & $25(69)$ & $16(70)$ & 0.128 \\
\hline $\begin{array}{l}\text { Peak flow (1/min) } \\
\text { Mean (SD) }\end{array}$ & $\begin{array}{l}n=78 \\
477.18(107.73)\end{array}$ & $\begin{array}{l}n=26 \\
447.50(148.04)\end{array}$ & $\begin{array}{l}n=16 \\
493.94(103.20)\end{array}$ & 0.400 \\
\hline $\begin{array}{l}\text { AT-VE/VO2 } \\
\text { Mean (SD) }\end{array}$ & $\begin{array}{l}n=57 \\
32.19(5.15)\end{array}$ & $\begin{array}{l}n=30 \\
33.63(5.97)\end{array}$ & $\begin{array}{l}n=17 \\
31.94(4.35)\end{array}$ & 0.387 \\
\hline $\begin{array}{l}\text { Operative fluid balance (liter) } \\
\text { Mean (SD) }\end{array}$ & $2.44(1.23)$ & $2.71(1.25)$ & $2.30(1.29)$ & 0.387 \\
\hline $\begin{array}{l}\text { Preoperative Hemoglobin (g/l) } \\
\text { Median (IQR) }\end{array}$ & $130(120-137)$ & $132(116-143)$ & $135(122-144)$ & 0.339 \\
\hline $\begin{array}{l}\text { Preoperative Albumin }(\mathrm{g} / \mathrm{I}) \\
\text { Median }(I Q R)\end{array}$ & $40(24-42)$ & $39(37-41)$ & $40(39-42)$ & 0.277 \\
\hline $\begin{array}{l}\text { Highest lactate (mmol/l) } \\
\text { Median (IQR) }\end{array}$ & $1.20(0.9-1.7)$ & $1.30(1.15-1.95)$ & $1.25(1.10-1.70)$ & 0.397 \\
\hline
\end{tabular}

WHO PS: World Health Organisation Performance status; $n$ : Number; I/min: Litres per minute; AT- VE/VCO2: Minute ventilation/carbon dioxide production at Anaerobic Threshold; SD: Standard Deviation; IQR: Interquartile Range; g/l: Grams per litre; mmol/I: Millimole per litre.

Table 7: Factors not significant with univariate analysis of peri-operative factors associated with having an elective or delayed tracheostomy.

\begin{tabular}{|c|c|c|c|c|}
\hline \multirow[b]{2}{*}{ Variables } & \multicolumn{2}{|l|}{ No vs. Elective } & \multicolumn{2}{|l|}{ No vs. Delayed } \\
\hline & $\operatorname{RRR}(95 \% \mathrm{Cl})$ & p-value & $\operatorname{RRR}(95 \% \mathrm{Cl})$ & p-value \\
\hline Age & $1.02(0.98-1.06)$ & 0.989 & $0.98(0.93-1.02)$ & 0.303 \\
\hline $\begin{array}{l}\text { Gender: } \\
\text { Female } \\
\text { Male }\end{array}$ & $\begin{array}{l}1 \\
1.45(0.45-4.69)\end{array}$ & 0.539 & $\begin{array}{l}1 \\
1.90(0.40-8.95)\end{array}$ & 0.418 \\
\hline $\begin{array}{l}\text { Nodes } \\
\text { negative } \\
\text { positive }\end{array}$ & $\begin{array}{l}1 \\
0.62(0.28-1.38)\end{array}$ & 0.239 & $\begin{array}{l}1 \\
1.54(0.61-3.84)\end{array}$ & 0.359 \\
\hline $\begin{array}{l}\text { WHO PS } \\
0 \\
1 \\
2 \\
3\end{array}$ & $\begin{array}{l}1 \\
1.18(0.51-2.72) \\
4.33(1.01-18.49) \\
1.73(0.15-20.64)\end{array}$ & $\begin{array}{l}0.701 \\
0.048 \\
0.664\end{array}$ & $\begin{array}{l}1 \\
1.17(0.44-3.09) \\
2.5(0.40-15.77) \\
2.5(0.20-30.60)\end{array}$ & $\begin{array}{l}0.751 \\
0.330 \\
0.472\end{array}$ \\
\hline $\begin{array}{l}\text { Dietician inpu } \\
\text { No } \\
\text { Yes }\end{array}$ & $\begin{array}{l}1 \\
2.01(0.89-4.53)\end{array}$ & 0.092 & $\begin{array}{l}1 \\
2.02(0.76-5.35)\end{array}$ & 0.156 \\
\hline $\begin{array}{l}\text { Surgical techn } \\
\text { Lap-assisted } \\
\text { Open }\end{array}$ & $\begin{array}{l}1 \\
1.25(0.58-2.69)\end{array}$ & 0.569 & $\begin{array}{l}1 \\
1.88(0.73-4.82)\end{array}$ & 0.192 \\
\hline
\end{tabular}


Citation: Gerstman M, Batty J, Friedlaender G, et al. (2021) Perioperative Factors Associated with Tracheostomy use following Esophagectomy Surgery. J Clin Anesth Pain Manag 5(1):186-195

\begin{tabular}{|l|l|l|l|l|}
\hline $\begin{array}{l}\text { Neoadjuvant Chemo } \\
\text { No }\end{array}$ & 1 & & \\
\hline Yes & $1.00(0.36-2.82)$ & 0.993 & 1 & 0.334 \\
\hline Preoperative HB & $1.00(0.99-1.00)$ & 0.673 & $1.00(0.99-1.01)$ & 0.785 \\
\hline Pre-op albumin & $0.96(0.88-1.06)$ & 0.438 & $1.04(0.92-1.18)$ & 0.490 \\
\hline AT work & $0.99(0.97-1.01)$ & 0.261 & $1.00(0.98-1.02)$ & 0.739 \\
\hline AT-VE/VO2 & $1.05(0.97-1.15)$ & 0.229 & $0.98(0.89-1.09)$ & 0.762 \\
\hline FEV1 & $0.81(0.45-1.46)$ & 0.481 & $0.45(0.18-1.11)$ & 0.083 \\
\hline FVC & $0.76(0.45-1.26)$ & 0.288 & $0.49(0.22-1.09)$ & 0.081 \\
\hline Peak flow & $1.00(0.99-1.00)$ & 0.263 & $1.00(1.00-1.01)$ & 0.595 \\
\hline Intraoperative fluid & $1.00(0.99-1.00)$ & 0.067 & $1.00(0.99-1.00)$ & 0.839 \\
\hline Blood loss & $1.00(0.99-1.00)$ & 0.242 & $1.00(0.99-1.00)$ & 0.532 \\
\hline Highest lactate & $1.13(0.64-2.00)$ & 0.669 & $1.09(0.54-2.19)$ & 0.807 \\
\hline
\end{tabular}

RRR: Relative Risk Ratio; WHO PS: World Health Organisation Performance status; pre-op: Pre-operative; HB: Hemoglobin; AT: Anaerobic threshold; AT- VE/VCO2: Minute ventilation/carbon dioxide production at Anaerobic Threshold; FEV1: Forced Expiratory Volume in one second; FVC: Forced Vital Capacity.

Table 8: Other outcome data.

\begin{tabular}{|c|c|c|c|c|c|}
\hline Variables & Tracheostomy & $\begin{array}{l}\text { No } \\
\text { n (\%) }\end{array}$ & $\begin{array}{l}\text { Yes } \\
\text { n (\%) }\end{array}$ & Odds Ratio (95\% Cl) & p-value \\
\hline Renal & $\begin{array}{l}\text { No } \\
\text { Delayed } \\
\text { Elective }\end{array}$ & $\begin{array}{l}97(99) \\
22(96) \\
35(97)\end{array}$ & $\begin{array}{l}1(1) \\
1(4) \\
1(3)\end{array}$ & $\begin{array}{l}1 \\
4.41(0.27-73.25) \\
2.77(0.17-45.51)\end{array}$ & 0.525 \\
\hline Cardiovascular & $\begin{array}{l}\text { No } \\
\text { Delayed } \\
\text { Elective }\end{array}$ & $\begin{array}{l}78(80) \\
16(70) \\
25(69)\end{array}$ & $\begin{array}{l}20(20) \\
7(30) \\
11(31)\end{array}$ & $\begin{array}{l}1 \\
1.71(0.62-4.71) \\
1.72(0.72-4.07)\end{array}$ & 0.359 \\
\hline Neurological & $\begin{array}{l}\text { No } \\
\text { Delayed } \\
\text { Elective }\end{array}$ & $\begin{array}{l}90(92) \\
19(83) \\
32(89)\end{array}$ & $\begin{array}{l}8(8) \\
4(17) \\
4(11)\end{array}$ & $\begin{array}{l}1 \\
2.37(0.65-8.68) \\
1.41(0.40-4.99)\end{array}$ & 0.411 \\
\hline Wound & $\begin{array}{l}\text { No } \\
\text { Delayed } \\
\text { Elective }\end{array}$ & $\begin{array}{l}94(96) \\
20(87) \\
35(97)\end{array}$ & $\begin{array}{l}4(4) \\
3(13) \\
1(3)\end{array}$ & $\begin{array}{l}1 \\
3.53(0.73-16.99) \\
0.67(0.73-6.22)\end{array}$ & 0.164 \\
\hline Infectious & $\begin{array}{l}\text { No } \\
\text { Delayed } \\
\text { Elective }\end{array}$ & $\begin{array}{l}84(86) \\
17(73) \\
30(83)\end{array}$ & $\begin{array}{l}14(14) \\
6(26) \\
6(17)\end{array}$ & $\begin{array}{l}1 \\
2.12(0.71-6.29) \\
1.20(0.42-3.41)\end{array}$ & 0.391 \\
\hline
\end{tabular}

Table 9: Reason for tracheostomy insertion in delayed tracheostomy group.

\begin{tabular}{|l|l|l|l|l|}
\hline Age & Sex & BMI & Day tracheostomy inserted & Reason for tracheostomy \\
\hline 49 & MALE & 36 & 2 & SIRS, ventilation difficulties, likely prolonged respiratory wean \\
\hline 58 & MALE & 30 & 19 & Pneumonia, multiorgan failure \\
\hline 71 & MALE & 23 & 10 & Pneumonia, multiorgan failure \\
\hline 64 & MALE & 30 & 6 & Pneumonia, Ankylosing spondylitis \\
\hline 64 & MALE & 20 & 8 & $\begin{array}{l}\text { Failed extubation, bilateral pneumothoracies, pneumonia, } \\
\text { inappropriate neurologically, possible transient vocal cord palsy }\end{array}$ \\
\hline 66 & MALE & 32 & 3 & Pneumonia, multiorgan failure \\
\hline 76 & MALE & 27 & 9 & Surgical complication then ventilation difficulties \\
\hline 53 & MALE & 22 & 10 & Pneumonia, thoracic duct leak \\
\hline 54 & MALE & 37 & 13 & Ventilatory failure secondary pneumonia \\
\hline
\end{tabular}


Citation: Gerstman M, Batty J, Friedlaender G, et al. (2021) Perioperative Factors Associated with Tracheostomy use following Esophagectomy Surgery. J Clin Anesth Pain Manag 5(1):186-195

\begin{tabular}{|l|l|l|l|l|}
\hline 40 & MALE & 34 & 1 & Failed extubation, inadequate cough and inappropriate neurologically \\
\hline 65 & MALE & 30 & 6 & Pneumonia, likely prolonged respiratory wean \\
\hline 51 & FEMALE & 32 & 1 & Pneumonia, ventilation difficulties \\
\hline 55 & MALE & 28 & 2 & Lung contusions, ventilation difficulties \\
\hline 57 & MALE & 28 & 2 & Pneumonia, likely prolonged respiratory wean \\
\hline 71 & MALE & 29 & 3 & SIRS, likely prolonged respiratory wean \\
\hline 66 & MALE & 25 & 1 & $\begin{array}{l}\text { Bleeding surface pleura with return theatre, likely prolonged } \\
\text { respiratory wean }\end{array}$ \\
\hline 63 & MALE & 39 & 4 & Pneumonia, multiorgan failure, likely prolonged respiratory wean \\
\hline 72 & FEMALE & 32 & 3 & Pneumonia, high secretion load, difficulty ventilation \\
\hline 56 & MALE & 26 & 5 & Pneumonia, high secretion load, likely prolonged respiratory wean \\
\hline 73 & MALE & 31 & 2 & Pneumonia, likely prolonged respiratory wean \\
\hline 62 & MALE & 33 & 6 & Biliary leak, ST elevation, likely long respiratory wean \\
\hline 45 & MALE & 40 & 2 & SIRS likely prolonged respiratory wean \\
\hline 56 & MALE & 29 & 7 & $\begin{array}{l}\text { Pneumonia, poor cough, unable to clear secretions on extubation, } \\
\text { required reintubation }\end{array}$ \\
\hline
\end{tabular}

DOI: $10.36959 / 377 / 352$

Copyright: (C) 2021 Gerstman M, et al. This is an open-access article distributed under the terms of the Creative Commons Attribution License, which permits unrestricted use, distribution, and reproduction in any medium, provided the original author and source are credited. 